\title{
Breast Self-Examination Practice Among Women in Jimma, Southwest Ethiopia: A Community-Based Cross-Sectional Study
}

This article was published in the following Dove Press journal: Breast Cancer: Targets and Therapy

\section{Yonas Biratu Terfa (iD) Ebissa Bayana Kebede (D) Adugna Olani Akuma (iD}

Jimma University, Institute of Health, Faculty of Health Sciences, School of Nursing, Jimma, Ethiopia
Correspondence: Yonas Biratu Terfa Jimma University, Institute of Health Science, Faculty of Health, School of Nursing, Jimma, Ethiopia

Email yonibirre@gmail.com
Introduction: Breast self-examination is one of the cheapest screening methods for early detection of breast cancer which can be performed by women in privacy, and in their own schedule. Despite being simple, quick, and cost-free, the practice of breast self-examination is low. The study was carried out to assess the practice of breast self-examination among women of childbearing age in Jimma, Southwest Ethiopia.

Objective: To assess the practice of breast self-examination among women of childbearing age in Jimma, Southwest Ethiopia.

Methods: A community-based cross-sectional study was conducted in Jimma town, Southwest Ethiopia in March 2018. Seven hundred and twenty-four women of childbearing age were selected by multistage sampling methods. They were interviewed using structured questionnaire and standardized scale. Bivariate logistic regression analysis was done to see crude association between each independent variable and outcome variable. Logistic regression was used for analysis on the basis of OR, 95\% CI and a P value of less than 0.05 .

Results: Six hundred and eighty-six respondents participated in the study giving $94.7 \%$ of response rate. Only $15 \%$ of them practiced breast self-examination. Respondents age (AOR = 2.07/1.14, 3.74/0.01), occupation ( $\mathrm{AOR}=3.93 / 1.49,10.35 / 0.00)$, family history of breast cancer $(\mathrm{AOR}=4.16 / 2.35,7.36 / 0.00)$ and monthly income $(\mathrm{AOR}=5.57 / 1.55,19.92 / 0.00)$ are significantly associated with women's practice of breast self-examination at a P-value less than 0.05

Conclusion: The practice of breast self-examination is very low. Respondent age, occupation, family history of breast cancer, and monthly income are significantly associated with the women's practice of breast self-examination.

Keywords: breast, breast self-examination, childbearing

\section{Introduction}

Breast cancer is the most common and the leading cause of death among women worldwide as well as in Ethiopia. ${ }^{1,2}$ The incidence rate of breast cancer is increasing rapidly across the world and in resource-stricken developing countries a high proportion of women present for health care in the advanced stages of the disease. ${ }^{3}$

In sub-Saharan Africa high cancer related mortality rate is occurs due to poor community awareness about breast cancer and its screening practices. ${ }^{4}$ Breast cancer knowledge plays an important role in increasing risk reduction behaviors, promoting timely cancer screening, enhancing early case detection, and ultimately reducing the cancer burden. ${ }^{5}$ The low survival rate in developing countries can be 
related to the lack of suitable early screening program resulting in a high percent of women presenting with advanced stage disease, as well as by the lack of adequate diagnostic and treatment facilities. ${ }^{6}$

Breast cancer screening and early detection is the key strategy in reducing breast cancer related mortality and distant complication and signifies a better outcome. ${ }^{4}$ Breast self-examination (BSE) is one important method of early detection of breast cancer depending on a woman's age. ${ }^{2}$

BSE is one of the cheapest screening methods for early detection that women can do by themselves, in private, and in their own schedule and more than $90 \%$ of cases of breast cancer can be detected by women themselves through BSE. ${ }^{7,8}$ BSE is a simple, quick, and cost-free procedure, ${ }^{9}$ which is not only appropriate, cost-effective and acceptable technique of early detection of breast cancer, but also helps childbearing women to be involved in preventive health. ${ }^{10}$

Despite the many benefits of BSE, only a few childbearing women practice it due to poor knowledge about screening methods. ${ }^{8,9,11}$ In Ethiopia the knowledge and practice level of BSE at community level is unknown and most of the studies have been conducted on university students, ${ }^{12-}$ 15 and health care providers. ${ }^{16-18}$ Due to this, many women miss early detection as well as treatment opportunities due to poor practice level of BSE. ${ }^{19}$ Thus, this study planned to assess the level BSE knowledge and practice among reproductive age group women in Jimma town.

\section{Materials and Methods Study Design and Setting}

A community-based cross-sectional study design was conducted from March 01 to March 31, 2018 in Jimma town, Oromia regional state, southwest Ethiopia. Jimma town is located $352 \mathrm{~km}$ southwest of Addis Ababa. Based on data 2016 from the town administration, it has a total population of 195,443. The town has 17 kebeles. The town has a total of 128 health institutions; one referral hospital, one governmental and one private hospital, 4 governmental health centers, 55 private clinics, 25 pharmacies, 36 drug stores, and 5 drug distributors which are providing health service in Jimma city.

\section{Study Population}

All randomly selected women of childbearing age group (15-49 years) living in the selected kebeles of Jimma town constituted the study population. Women residing more than
6 months in the selected kebeles of Jimma town and had interest in participating in the study were included the study. Non-Ethiopians or foreigners and pregnant women were excluded.

\section{Study Variables}

Dependent variable: - Practice of BSE

Independent variables: -

- Socio demographic characteristics (age, occupation, educational status, income, marital status)

- Family history of breast cancer

- Personal history of breast cancer

- Knowledge of BSE

- Knowledge of early danger signs breast cancer

\section{Sample Size Determination}

Sample size was determined using sample size formula for estimating a single population proportion with a margin of error of $5 \%$, confidence interval of $95 \%$, and assumption of design effect of $2 \%$ and expected non-response rate of $5 \%$. It is calculated based on the proportion of knowledge of breast cancer $31.1 \%{ }^{12}$

$$
\begin{aligned}
\mathrm{n} & =\frac{(\mathrm{Z} a / 2) 2 \mathrm{P}(1-\mathrm{P})}{\mathrm{d}^{2}}=\frac{(1.96)^{2} 0.311(1-0.311)}{(0.05)^{2}} \\
& =329
\end{aligned}
$$

After adding $10 \%$ for non-response rate and $2 \%$ of design effect the final sample size was 724 .

\section{Sampling Technique}

We used lists of kebeles developed by the Jimma city administration in Ethiopia. Five kebeles were randomly selected and the predetermined study sample was proportionally allocated to each of these kebeles. Women were selected by systematic random sampling to obtain the sample size.

\section{Data Collection Tools and Procedure}

Data was collected using a standard questionnaire developed by cancer research UK. ${ }^{20}$ The questionnaire was first prepared in English and then translated to both local language Afaan Oromo and Amharic by experts and then translated back to English. Data collection was carried out by ten trained Bsc Nurse and two supervisors with previous experience of data collection. 


\section{Data Quality Assurance}

To assure the quality of data collection tool Pre-test was conducted on $5 \%$ of the sample at Agero town to identify any weakness in the organization and structuring of the research instruments. Adequate training and supervision were provided for the data collectors and the supervisor. The filled questionnaire was checked for completeness by supervisor every day.

\section{Data Analysis Procedure}

After checking for completeness data were entered using Epi Data version 3.1 and exported to statistical Package for Social Sciences (SPSS) version 25 for analysis. Descriptive statistics were used to describe the study frequency and

Table I Distribution of Respondent's' Background Characteristics Among Childbearing Age Group Women of Jimma Town, Oromia Region, Southwest Ethiopia, 2018

\begin{tabular}{|c|c|c|c|}
\hline Variables & $\begin{array}{l}\text { Response } \\
\text { Category }\end{array}$ & $\begin{array}{l}\text { Frequency } \\
(\mathrm{N}=686)\end{array}$ & Percent \\
\hline Age (years) & $\begin{array}{l}15-35 \\
36-49\end{array}$ & $\begin{array}{l}496 \\
190\end{array}$ & $\begin{array}{l}72.3 \\
27.7\end{array}$ \\
\hline Educational status & $\begin{array}{l}\text { Secondary } \\
\text { education } \\
(9-12) \\
\text { Primary } \\
\text { school (I-8) } \\
\text { College and } \\
\text { above } \\
\text { No formal } \\
\text { Education }\end{array}$ & $\begin{array}{l}307 \\
169 \\
129 \\
81\end{array}$ & $\begin{array}{l}44.8 \\
24.6 \\
18.8 \\
11.8\end{array}$ \\
\hline Marital status & $\begin{array}{l}\text { Married } \\
\text { Single } \\
\text { Widowed } \\
\text { Divorced/ } \\
\text { separated }\end{array}$ & $\begin{array}{l}488 \\
73 \\
62 \\
63\end{array}$ & $\begin{array}{l}71.1 \\
10.6 \\
9.0 \\
9.2\end{array}$ \\
\hline Occupation & $\begin{array}{l}\text { Employed } \\
\text { House wife } \\
\text { Farmer } \\
\text { Private } \\
\text { Business }\end{array}$ & $\begin{array}{l}318 \\
211 \\
128 \\
29\end{array}$ & $\begin{array}{l}46.4 \\
30.8 \\
18.7 \\
4.2\end{array}$ \\
\hline $\begin{array}{l}\text { Family history of } \\
\text { breast cancer }\end{array}$ & $\begin{array}{l}\text { Yes } \\
\text { No }\end{array}$ & $\begin{array}{l}81 \\
605\end{array}$ & $\begin{array}{l}11.8 \\
88.2\end{array}$ \\
\hline $\begin{array}{l}\text { Personal History of } \\
\text { breast cancer }\end{array}$ & $\begin{array}{l}\text { Yes } \\
\text { No }\end{array}$ & $\begin{array}{l}75 \\
611\end{array}$ & $\begin{array}{l}10.9 \\
89.1\end{array}$ \\
\hline Monthly income & $\begin{array}{l}\text { Low income } \\
\text { Middle income } \\
\text { High income }\end{array}$ & $\begin{array}{l}426 \\
211 \\
49\end{array}$ & $\begin{array}{l}62.1 \\
30.8 \\
7.1\end{array}$ \\
\hline
\end{tabular}

percentage for categorical variables. To assess the association between dependent and independent variables by controlling for confounders Binary Logistic regression analysis was carried out and all variables with p-value less than 0.25 in bi-variate analysis was considered as candidates for multiple logistic regression analysis to identify a variable which has a significant association on the basis of OR, with $95 \% \mathrm{CI}$ and P-value of less than 0.05 .

\section{Results}

\section{Socio-Demographic Characteristics of the Respondents}

From seven hundred twenty-four women, 686 women completed the interview which gives a response rate of

Table 2 Distribution of Respondent's Knowledge of BSE Among Childbearing Age Group Women of Jimma Town, Oromia Region, Southwest Ethiopia, 2018

\begin{tabular}{|c|c|c|c|}
\hline Variables & & Frequency & Percent \\
\hline $\begin{array}{l}\text { Breast self-examination is the } \\
\text { assessment made on the breast by an } \\
\text { individual to check for breast lumps. }\end{array}$ & $\begin{array}{l}\text { Yes } \\
\text { No }\end{array}$ & $\begin{array}{l}266 \\
420\end{array}$ & $\begin{array}{l}38.8 \\
61.2\end{array}$ \\
\hline $\begin{array}{l}\text { Breast self-examination should be } \\
\text { done every month }\end{array}$ & $\begin{array}{l}\text { Yes } \\
\text { No }\end{array}$ & $\begin{array}{l}221 \\
465\end{array}$ & $\begin{array}{l}32.2 \\
67.8\end{array}$ \\
\hline $\begin{array}{l}\text { Examining breasts is done } \mathrm{I}-7 \text { days } \\
\text { after the end of menstrual period }\end{array}$ & $\begin{array}{l}\text { Yes } \\
\text { No }\end{array}$ & $\begin{array}{l}192 \\
494\end{array}$ & $\begin{array}{l}28 \\
72\end{array}$ \\
\hline $\begin{array}{l}\text { Breast self-examination is done } \\
\text { looking at breasts in the mirror }\end{array}$ & $\begin{array}{l}\text { Yes } \\
\text { No }\end{array}$ & $\begin{array}{l}201 \\
485\end{array}$ & $\begin{array}{l}29.3 \\
70.7\end{array}$ \\
\hline $\begin{array}{l}\text { Breast self-examination is done } \\
\text { with arms raised over head }\end{array}$ & $\begin{array}{l}\text { Yes } \\
\text { No }\end{array}$ & $\begin{array}{l}215 \\
471\end{array}$ & $\begin{array}{l}31.3 \\
68.7\end{array}$ \\
\hline $\begin{array}{l}\text { Examining one's breast is possible } \\
\text { while lying down }\end{array}$ & $\begin{array}{l}\text { Yes } \\
\text { No }\end{array}$ & $\begin{array}{l}194 \\
492\end{array}$ & $\begin{array}{l}28.3 \\
71.7\end{array}$ \\
\hline $\begin{array}{l}\text { In breast self-examination, the } \\
\text { women need to look for lumps } \\
\text { using tips of fingers }\end{array}$ & $\begin{array}{l}\text { Yes } \\
\text { No }\end{array}$ & $\begin{array}{l}151 \\
535\end{array}$ & $\begin{array}{l}22 \\
78\end{array}$ \\
\hline $\begin{array}{l}\text { Breast self-examination is done in } \\
\text { a circular, clockwise motion moving } \\
\text { from outside in }\end{array}$ & $\begin{array}{l}\text { Yes } \\
\text { No }\end{array}$ & $\begin{array}{l}196 \\
490\end{array}$ & $\begin{array}{l}28.6 \\
71.4\end{array}$ \\
\hline $\begin{array}{l}\text { In breast self-examination, the } \\
\text { women need to squeeze the nipples } \\
\text { of each breast to look for discharge }\end{array}$ & $\begin{array}{l}\text { Yes } \\
\text { No }\end{array}$ & $\begin{array}{l}197 \\
459\end{array}$ & $\begin{array}{l}28.7 \\
71.3\end{array}$ \\
\hline $\begin{array}{l}\text { When examining breast, feel for } \\
\text { lumps, thickening and look for } \\
\text { lumps under armpits }\end{array}$ & $\begin{array}{l}\text { Yes } \\
\text { No }\end{array}$ & $\begin{array}{l}184 \\
502\end{array}$ & $\begin{array}{l}26.8 \\
73.2\end{array}$ \\
\hline $\begin{array}{l}\text { Examining breast should begin at } \\
\text { age } 20\end{array}$ & $\begin{array}{l}\text { Yes } \\
\text { No }\end{array}$ & $\begin{array}{l}157 \\
529\end{array}$ & $\begin{array}{l}22.9 \\
77.1\end{array}$ \\
\hline
\end{tabular}


94.7\%. Majority 496 (72.3\%) of the respondents were young adults with mean age 31 years, most women 307 (44.8\%), had completed secondary school but one-tenth of the participants had no formal education. Four hundred and eighty-eight (71.1\%) were married, 318 (46.4\%) were government employees, with monthly salary $\leq$ ETB 1380 (USD 40). Eighty-one (11.8\%) women had a family history of breast cancer and 75 (10.9\%) were survivors of breast cancer. (Table 1)

\section{Knowledge of BSE}

Concerning the overall knowledge of BSE, $43.1 \%$ of the respondents had a good knowledge score. About 266 (38.8\%) of the respondents knew the correct definition of breast self-examination and among the procedures of BSE, that women need to look for lumps using tips of fingers is only known by 151 (22\%) of the women. (Table 2).

\section{Practice of BSE}

Only 103 (15\%) women practiced breast self-examination. (Figure 1).

Among the total of 103 respondents who practiced BSE, only less than half of them 47 (45.7\%) were doing the breast self-examination regularly (monthly) and 49 (47.6\%) knew the appropriate time for performing BSE (Table 3).

\section{Reason for Practicing BSE}

Relatively high percent 43 (41.7\%) of respondents practiced the BSE due to a family pressure and one fourth $25(24.3 \%)$ of the respondents practiced BSE based on information provided by mass media (Figure 2).

\section{Reason for Not Practicing BSE}

More than five sixth, 583 (85\%) women did not practice BSE. The two main reasons for not practicing were lack of knowledge and absence of breast problem, 133 (22.8\%) and 117 (20.1\%) respectively. (Figure 3).

\section{Factors Associated with Practice of BSE}

The association of different background factors of the respondents with knowledge of breast self-examination was investigated using binary logistic regression analysis. Based on binary logistic regression variables, which include age, educational status, occupation, family history of breast cancer, and income are candidate variable for multiple logistic regression. In the final model; age, occupation, family history of breast cancer, and income are statistically significant with BSE practice in the model. However, no significant association was observed between educational status and BSE practice.

Women aged 35 years and below were 2 times $(\mathrm{AOR}=$ $2.072 / 1.146,3.747 / 0.016)$ more likely to practice BSE than women older than 35 years. Employed women were four times $(\mathrm{AOR}=3.936 / 1.497,10.351 / 0.005)$ more likely practice BSE than housewife women. A woman who had a family history of breast cancer were 4.2 times (AOR = $4.167 / 2.358,7.364 / 0.000$ ) more likely practice BSE than women who had no family history of breast cancer.

Regarding monthly income, women who earned between 1380 Ethiopian birr (40 Dollar) and 2872 Ethiopian birr (82 Dollar) monthly were 5.57 times $(\mathrm{AOR}=5.570 / 1.557,19.922 / 0.008)$ more likely to practice BSE than women who earned less than 1380 Ethiopian birr (40 Dollar) monthly (Table 4).

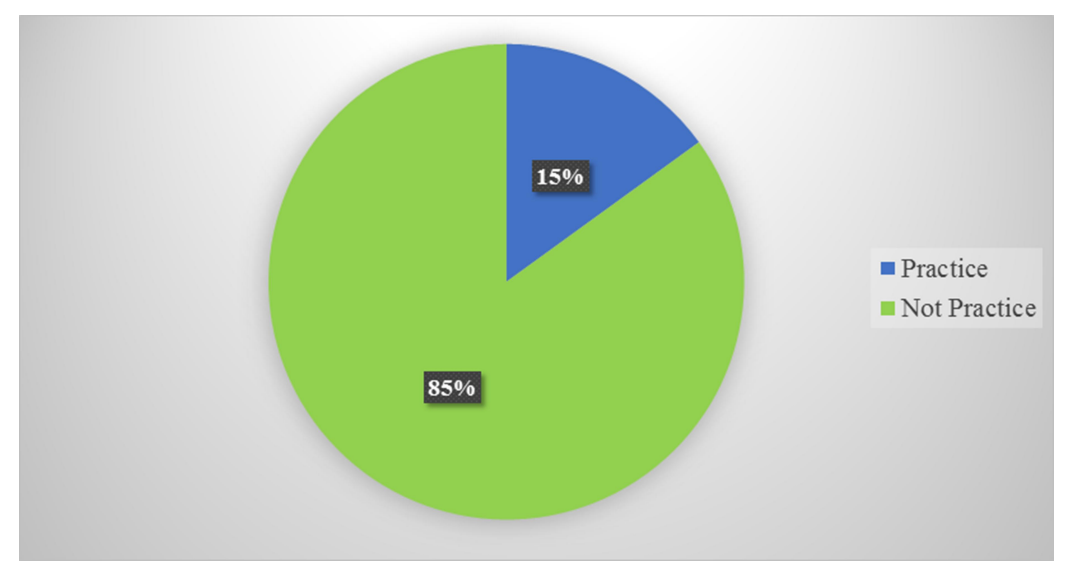

Figure I Respondent's breast self-examination practice levels among childbearing age group women of Jimma town, Oromia region, southwest Ethiopia, 2018. 
Table 3 Respondent's Breast Self-Examination Practice Frequency and Appropriate Time Distribution Among Childbearing Age Group Women of Jimma Town, Oromia Region, Southwest Ethiopia, 2018

\begin{tabular}{|l|l|l|l|}
\hline \multicolumn{2}{|l|}{ Variables } & Frequency & No \\
\hline $\begin{array}{l}\text { Have you ever examined your breast } \\
\text { by your hands }\end{array}$ & Yes & 103 & 15 \\
No & 583 & 85 \\
\hline How frequently do you practice & Frequency & Percent \\
Weekly & 1 I & 10.7 \\
Monthly & 47 & 45.6 \\
Annually & 28 & 27.2 \\
When I remember but not regular & 17 & 16.5 \\
\hline Appropriate time for performing breast & Frequency & Percent \\
self-examination & & \\
I -7 days after menstruation & 49 & 47.6 \\
Before menstruation & 15 & 14.6 \\
At any time & 39 & 37.9 \\
\hline
\end{tabular}

\section{Discussion}

This study revealed less than one sixth (15\%) of women of childbearing age living in Jimma town practiced breast selfexamination. Among them only $47(6.8 \%)$ were regularly performing breast self-examination every month. However, only $47(6.8 \%)$ of the respondent were doing breast selfexamination regularly (monthly). This shows that more than $85 \%$ of the women did not benefit from the importance of early case detection BSE which may prevent potential complications. This finding is lower than with other studies conducted in Ethiopia, ${ }^{16,17}$ in which breast self-examination practice was $32.6 \%$ and $32.5 \%$, respectively, the gap might be due to the differences in the study subjects. Because, those studies were conducted on health care workers who had a better awareness and experience in breast self-examination. However, the current study was done on all women at community level regardless of their professional background.

This study is in line with studies conducted in Vietnam and Cameroon, ${ }^{21,22}$ however, it is lower than studies conducted in Indonesia, ${ }^{23}$ Nigeria, ${ }^{24}$ and Ghana. ${ }^{25}$ This differences may be due to differences in study area, period, subject and methodological difference. The current finding implies that clinical usage of BSE is very poor, due to this reason majority of the women did not benefit from BSE to detect abnormality before reaching an advancing stage of breast cancer.

Occupation of the respondent was a significant variable in determining practice of BSE in this study and employed women were four times more likely practice BSE than homemakers, this might be an indication that mothers who were employed are more aware of breast cancer and its effects toward the practice of breast self-examination as they have better exposure to different kinds of information. This is similar to a study conducted in Nigeria. ${ }^{24}$

The current study revealed that younger aged women were two times more likely to practice BSE than those who are older than 35 years of age. This can be due to the fact that young women were giving more attention to their physical appearance and health than older aged women, which implies that as the participants age increases breast self-examination practice level decreases. This is similar to

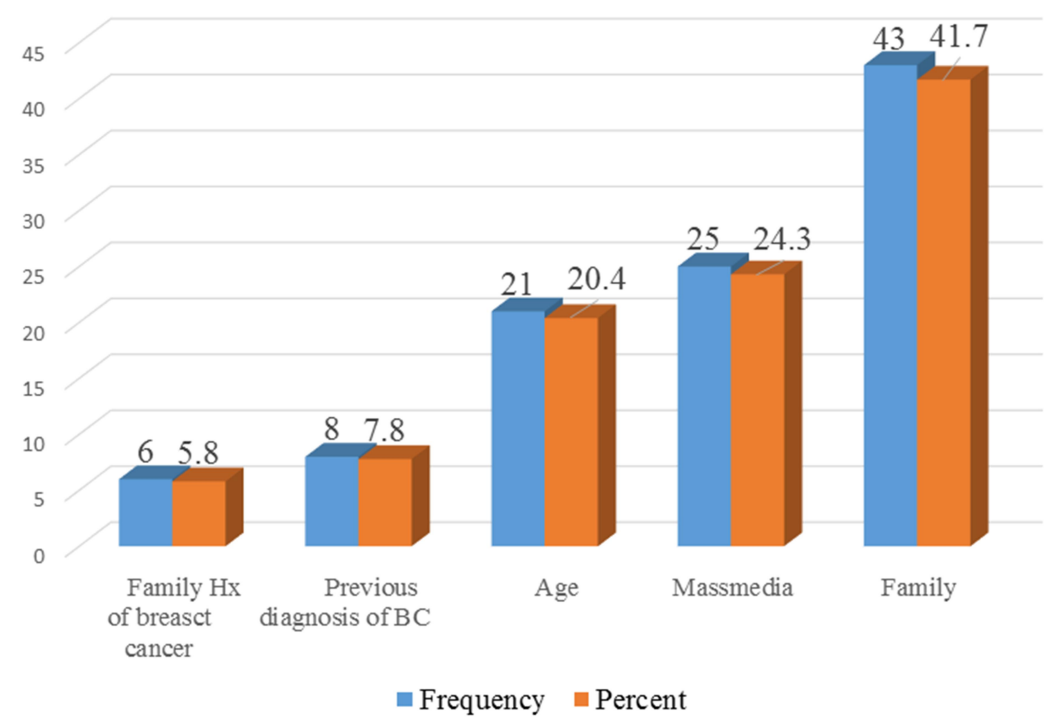

Figure 2 Respondent's reason for practicing breast self-examination distribution among childbearing age group women of Jimma town, Oromia region, southwest Ethiopia, 2018. $(\mathrm{N}=103)$. 


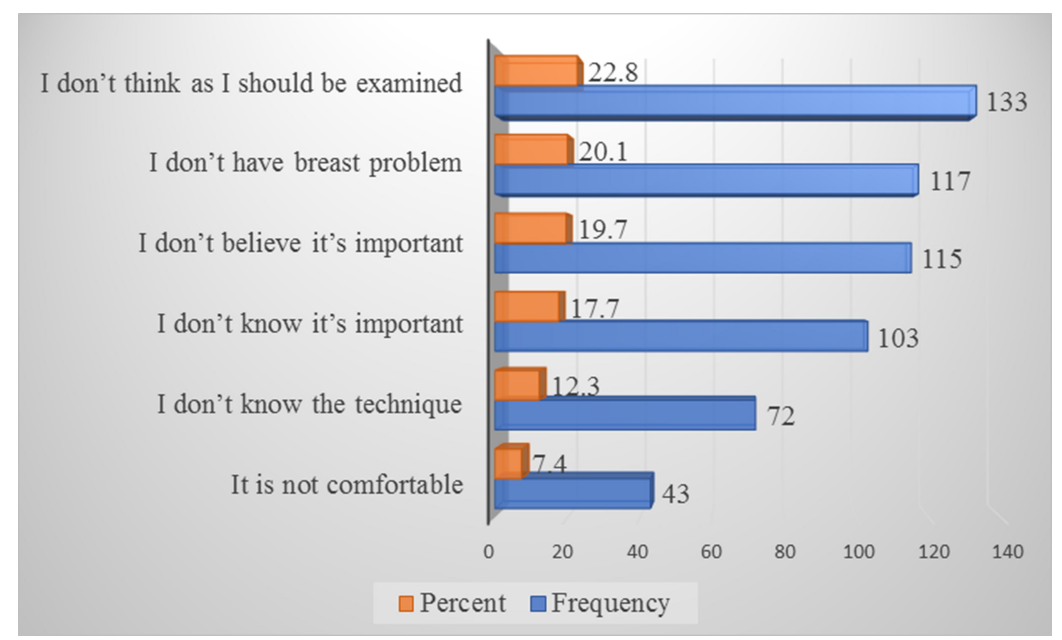

Figure 3 Respondent's reason for not practice breast self-examination distribution among childbearing age group women of Jimma town, Oromia region, southwest Ethiopia, 2018. $(\mathrm{N}=583)$.

a study conducted in Ghana, ${ }^{25}$ however, it is contrasted with a study in Indonesia. ${ }^{23}$ The discrepancy might be due to difference in the study area and socio-economic status.
The findings of the present study showed that women with a family history of breast cancer were four times more likely to practice BSE than women who did not

Table 4 The Association Between Socio-Demographic and Breast Self-Examination Practice of Respondents Among Childbearing Age Group Women of Jimma Town, Southwest Ethiopia, 2018

\begin{tabular}{|c|c|c|c|}
\hline Variables & COR/95\% Cl/P-value & AOR/95\% Cl/P-value & Variables \\
\hline Age (years) & $\begin{array}{l}21-35 \\
36-49\end{array}$ & $\begin{array}{l}I .835 / I .081,3.114 / 0.024 * \\
I\end{array}$ & $\begin{array}{l}2.072 / 1.146,3.747 / 0.016 * * \\
I\end{array}$ \\
\hline Educational status & $\begin{array}{l}\text { College and above } \\
\text { Secondary education } \\
\text { Primary school } \\
\text { No formal education }\end{array}$ & $\begin{array}{l}\text { I.208/0.589, } 2.479 / 0.606 \\
0.953 / 0.498,1.826 / 0.886 \\
0.366 / 0.161,0.833 / 0.017^{*} \\
\text { I }\end{array}$ & $\begin{array}{l}\text { I.809/0.737,4.442/0.196 } \\
\text { I.489/0.682,3.253/0.3I8 } \\
0.438 / 0.177, I .080 / 0.075 \\
\mathrm{I}\end{array}$ \\
\hline Marital status & $\begin{array}{l}\text { Divorced/separated } \\
\text { Single } \\
\text { Married } \\
\text { Widowed }\end{array}$ & $\begin{array}{l}0.675 / 0.279, \quad I .687 / 0.400 \\
I .290 / 0.767,2.170 / 00.337 \\
I .460 / 0.780,2.733 / 0.237 \\
I\end{array}$ & \\
\hline Occupation & $\begin{array}{l}\text { Employed } \\
\text { Private business } \\
\text { Farmer } \\
\text { House wife }\end{array}$ & $\begin{array}{l}3.916 / 1.637,9.367 / 0.002^{*} \\
1.672 / 0.762,3.671 / 0.200^{*} \\
1.264 / 0.877,1.823 / 0.210^{*} \\
0.869 / 0.540,1.399 / 0.563\end{array}$ & $\begin{array}{l}3.936 / I .497, \mid 10.35 \mathrm{I} / 0.005 \\
\mathrm{I} .402 / 0.790,2.469 / 0.242 \\
\mathrm{I} .598 / 0.743,3.437 / 0.230 \\
\mathrm{I}\end{array}$ \\
\hline Knowledge of breast self-examination & $\begin{array}{l}\text { Poor } \\
\text { Good }\end{array}$ & $\begin{array}{l}0.810 / 0.532, \mathrm{I} .233 / 0.326 \\
\mathrm{I} .00\end{array}$ & \\
\hline Family history of breast cancer & $\begin{array}{l}\text { Yes } \\
\text { No }\end{array}$ & $\begin{array}{l}4.002 / 2.390,6.699 / 0.000 * \\
\text { I }\end{array}$ & $4.167 / 2.358,7.364 / 0.000 * *$ \\
\hline Personal History of breast cancer & $\begin{array}{l}\text { Yes } \\
\text { No }\end{array}$ & $\begin{array}{l}\text { I.088/0.565,2.098/0.800 } \\
\text { I }\end{array}$ & \\
\hline Monthly income & $\begin{array}{l}\text { Low income } \\
\text { Middle income } \\
\text { High income }\end{array}$ & $\begin{array}{l}I .766 / 0.527,5.916 / 0.356 \\
5.554 / 1.657,18,526 / 0.005^{*} \\
\text { I }\end{array}$ & $\begin{array}{l}1.973 / 0.544,7.160 / 0.302 \\
5.570 / 1.557,19.922 / 0.008 \text { ** } \\
\text { I }\end{array}$ \\
\hline
\end{tabular}

Notes: $*$ Significant at $\mathrm{p}$ value $<0.25$. ${ }^{*}$ Significant at $\mathrm{p}$ value $<0.05>$. 
have family history of breast cancer. This implies that a family history of breast cancer is positively affecting the practice of breast self-examination. This is consistent with studies conducted in Indonesia, ${ }^{23}$ Nigeria, ${ }^{24}$ and Ethiopia. $^{15,16}$

\section{Limitation and Strength}

There are some limitations which may have influenced the findings in this study. There may be over and/or under estimating of their practices due to recall bias. In addition, the analysis might only identify the associations between exposure to risk factors and practice of BSE, but not fix the causality and the practice level of BSE. Despite its weakness by considering adequate sample size, community based, and first report in our setting on women at community level. We can conclude that the study finding represents the total population in the area.

For future we recommend a comprehensive community-based study at a national level on breast cancer screening practices in order to plan an awareness creation program and a longitudinal study for better outcome in all dimensions of breast screening practices.

\section{Conclusion}

The breast self-examination practice level of women of childbearing age living in Jimma town was very low (15\%) and only $47(6.8 \%)$ of the respondent were doing breast selfexamination regularly (monthly). From this study we can also conclude that maternal age, occupation, family history of breast cancer, and monthly income are significantly associated with women's practice of breast self-examination.

\section{Ethics and Consent}

This study was approved by the ethics committees of the Institutional Review Board of Jimma University. It adhered to the basics of the Declaration of Helsinki. A formal letter from the Institute of Health Science was submitted to selected kebeles and Jimma town municipality to obtain their cooperation and written informed consent was obtained from all the study subjects and femailes aged under 18 years were not included in this study.

\section{Acknowledgments}

We thank Jimma University, Institute of Health. Our thanks also go to supervisors, data collectors and study participants for their immense contribution in realization of our study. We want to thank Prof. Susan Anand for her contribution on proof reading.

\section{Author Contributions}

All authors made a significant contribution to the work reported, whether that is in the conception, study design, execution, acquisition of data, analysis and interpretation, or in all these areas; took part in drafting, revising or critically reviewing the article; gave final approval of the version to be published; have agreed on the journal to which the article has been submitted; and agree to be accountable for all aspects of the work.

\section{Disclosure}

We strongly clarify that there is no any financial and nonfinancial competing of interest among us and with other bodies.

\section{References}

1. Organization WH. Noncommunicable Diseases Country Profiles 2018; 2018.

2. Organization WH. WHO Report on Cancer: Setting Priorities, Investing Wisely and Providing Care for All; 2020.

3. Coughlin SS, Ekwueme DU. Breast cancer as a global health concern. Cancer Epidemiol. 2009;33(5):315-318. doi:10.1016/j. canep.2009.10.003

4. Jedy-Agba E, McCormack V, Adebamowo C, dos-Santos-Silva I. Stage at diagnosis of breast cancer in sub-Saharan Africa: a systematic review and meta-analysis. Lancet Glob Health. 2016;4 (12):e923-e35. doi:10.1016/S2214-109X(16)30259-5

5. Morhason-Bello IO, Odedina F, Rebbeck TR, et al. Challenges and opportunities in cancer control in Africa: a perspective from the African Organisation for Research and Training in Cancer. Lancet Oncol. 2013;14(4):e142-e51. doi:10.1016/S1470-2045(12) 70482-5

6. Rivera-Franco MM, Leon-Rodriguez E. Delays in breast cancer detection and treatment in developing countries. Breast Cancer. 2018;12:1178223417752677.

7. Nafissi N, Saghafinia M, Motamedi MHK, Akbari ME. A survey of breast cancer knowledge and attitude in Iranian women. $J$ Cancer Res Ther. 2012;8(1):46. doi:10.4103/0973-1482.95173

8. Suh MAB, Atashili J, Fuh EA, Eta VA. Breast self-examination and breast cancer awareness in women in developing countries: a survey of women in Buea, Cameroon. BMC Res Notes. 2012;5(1):1-6. doi:10.1186/1756-0500-5-627

9. Karayurt Ö, Özmen D, Çetinkaya AÇ. Awareness of breast cancer risk factors and practice of breast self examination among high school students in Turkey. BMC Public Health. 2008;8(1):359. doi:10.1186/1471-2458-8-359

10. UKEssays. Knowledge And Practice Of Breast Self Examination Nursing Essay [Internet]; November 2013. Available from: https:// www.uniassignment.com/essay-samples/nursing/knowledge-andpractice-of-breast-self-examination-nursing-essay.php?vref $=1$. Accessed September 17, 2020.

11. Smith RA, Caleffi M, Albert US, et al. Breast cancer in limitedresource countries: early detection and access to care. Breast $J$. 2006;12:S16-S26. doi:10.1111/j.1075-122X.2006.00200.x

12. Hailu T, Berhe H, Hailu D, Berhe H. Knowledge of breast cancer and its early detection measures among female students, in Mekelle University, Tigray region, Ethiopia. Science. 2014;3 (4):57-64. 
13. Kassa R, Wakjira H, Gebremariam M, Tullu S, Shehissa N. Breast cancer knowledge and breast self-examination practice among female students in Rift Valley University, Adama campus, Adama. J Womens Health Care. 2017;6(5).

14. Birhane K, Alemayehu M, Anawte B, et al. Practices of breast self-examination and associated factors among female debre berhan university students. Int J Breast Cancer. 2017;2017:1-6. doi:10.1155/ 2017/8026297

15. Getu MA, Kassaw MW, Tlaye KG, Gebrekiristos AF. Assessment of breast self-examination practice and its associated factors among female undergraduate students in Addis Ababa University, Addis Ababa, Ethiopia, 2016. Breast Cancer. 2019;11:21.

16. Dagne AH, Ayele AD, Assefa EM. Assessment of breast self-examination practice and associated factors among female workers in Debre Tabor Town public health facilities, North West Ethiopia, 2018: cross-sectional study. PLoS One. 2019;14(8): e0221356. doi:10.1371/journal.pone.0221356

17. Shallo SA, Boru JD. Breast self-examination practice and associated factors among female healthcare workers in West Shoa Zone, Western Ethiopia 2019: a cross-sectional study. BMC Res Notes. 2019;12(1):637. doi:10.1186/s13104-019-4676-3

18. Teferi S, Mezgebe T, Demissie M, Durgaprasada A. Knowledge about breast cancer risk-factors, breast screening method and practice of breast screening among female healthcare professionals working in governmental hospitals, Addis Ababa, Ethiopia. IOSR J Pharm Biol Sci. 2012;2(1):5-12. doi:10.9790/3008-0210512

19. Al-Azmy SF, Alkhabbaz A, Almutawa HA, Ismaiel AE, Makboul G, El-Shazly MK. Practicing breast self-examination among women attending primary health care in Kuwait. Alexandria $\mathrm{J} \mathrm{Med.}$ 2013;49(3):281-286. doi:10.1016/j.ajme.2012.08.009
20. UK CR. Cancer awareness measure (CAM) toolkit (version 2.1); 2011.

21. Tuyen DQ, Dung TV, Dong HV, Kien TT, Huong TT. Breast self-examination: knowledge and practice among female textile workers in Vietnam. Cancer Control. 2019;26(1):1073274819862788. doi:10.1177/1073274819862788

22. Azemfac K, Christie S, Carvalho MM, et al. A community-based assessment of knowledge and practice of breast self-examination and prevalence of breast disease in Southwest Cameroon. J Cancer Epidemiol. 2019;2019.

23. Dewi TK, Massar K, Ruiter RA, Leonardi T. Determinants of breast self-examination practice among women in Surabaya, Indonesia: an application of the health belief model. BMC Public Health. 2019;19 (1):1-8. doi:10.1186/s12889-019-7951-2

24. Ossai E, Azuogu B, Ogaranya I, Ogenyi A, Enemor D, Nwafor M. Predictors of practice of breast self-examination: A study among female undergraduates of Ebonyi State University, Abakaliki, Nigeria. Niger J Clin Pract. 2019;22(3):361.

25. Dadzi R, Adam A. Assessment of knowledge and practice of breast self-examination among reproductive age women in Akatsi South district of Volta region of Ghana. PLoS One. 2019;14(12): e0226925. doi:10.1371/journal.pone.0226925

\section{Publish your work in this journal}

Breast Cancer - Targets and Therapy is an international, peer-reviewed open access journal focusing on breast cancer research, identification of therapeutic targets and the optimal use of preventative and integrated treatment interventions to achieve improved outcomes, enhanced survival and quality of life for the cancer patient.
The manuscript management system is completely online and includes a very quick and fair peer-review system, which is all easy to use. Visit http://www.dovepress.com/testimonials.php to read real quotes from published authors. 